\title{
Effect of McConnell Patelar Taping on Walking Speed, Step Length, and Stride Length in Sub acute Stroke Patient
}

\author{
Cokorda Gde Bayu, Meisy Andriana*, Yudith Dian Prawitri \\ *Corresponding author: meisy1913@yahoo.com
}

Department of Physical Medicine and Rehabilitation, Faculty of Medicine Universitas Airlangga 60132, RSUD Dr. Soetomo, Suraba ya, Indonesia

\begin{abstract}
The purpose of this study is to analyse the effect of McConnell patellar taping on walking speed, step length and stride length in sub-acute stroke patient. This is an experimental study with pre-post-test analysis $(\mathrm{n}=8)$. The McConnell patelar taping placed on knee joint in paresis side for 30 minutes with McConnell technique and measured by gait analysis. This research placed in Physical Medicine and Rehabilitation outpatient clinic Dr Soetomo General Hospital. Eight sub-acute stroke patients participated in this study with average age $46.38 \pm 11.01$ years old and onset of stroke 3,87 $\pm 1,13$ months. The result of McConnell patelar taping application showed significant increase of walking speed, from $0,68 \pm 0,26 \mathrm{~m} / \mathrm{s}$ to $0.80 \pm 0.31 \mathrm{~m} / \mathrm{s}(\mathrm{p}<0,05)$. However, step length and stride length increased but not statically significant $(\mathrm{p}>0,05)$. From the result of this study, it appears that application of McConnell patellar taping for can increase walking speed in sub-acute stroke patient and thought be useful for sub-acute stroke patient for improvement on walking speed.

Keywords: McConnell patellar taping, sub-acute stroke, walking speed, step length, stride length
\end{abstract}

\section{Introduction}

Stroke is the leading cause of disability in the world. The prevalence of stroke in Indonesia based on the results of Riskesdas in 2018 is 10.9/ 1000 (permile) population. This continues to increase when compared to Riskesdas in 2013 (Riskesdas, 2018). Stroke is one of the causes of long-term disability. The most frequently encountered disabilities are gait disturbances. Disturbances in gait patterns are found in more than $80 \%$ of stroke patients. In stroke patients, there is often a decrease in the stance phase and a prolong swing phase from paresis side. There was also a decrease in walking speed, shortening of stride length and step length. Improvement of this gait pattern disorder is very important to do in order to improve the quality of life of the patients themselves (Li et al., 2018). There are many rehabilitation options for gait disturbance in stroke patients, one of which is patellar taping. This therapy was first introduced by McConnell, originally intended for the treatment of patellar chondromalacia, and is gaining popularity as an adjunct to therapy in persistent patellofemoral pain syndrome (PFPS) (Pfeiffer et al., 2004).

McConnell patellar taping aims to correct patellar tracking by making the patella move to medial. This improves the alignment of the patella and stability of the knee joint. In stroke patients, besides experiencing weakness in the extremities, there can also be patellar malalignment. The addition of McConnell patellar taping in patients with chronic stroke can improve dynamic balance and walking ability when compared to the placebo effect. This increase in walking ability can be seen from the increase in cadence, walking speed, step length and stride length (Shin et al., 2014). However, there is lack of research on the addition of McConnell patellar taping as an adjunct therapy for gait exercises. Therefore, the researcher believes that it is necessary to conduct a study 
to assess the improvement of walking function in sub acute stroke patients with the addition of McConnell patellar taping.

\section{Materials and Methods}

This study is experimental pre post test design. Data collection was carried out from March to October 2020 in Physical Medicine and Rehabilitation outpatient clinic and Gait Analysis Laboratory of Physical Medicine and Rehabilitation Installation at RSUD Dr. Soetomo Surabaya. The inclusion criteria for patients were : patients with subacute stroke (more than 2 weeks and less than 6 months), first or recurrent stroke, can walk independently $>10$ meters and stable, with or without a ambulation aid, able to climb stairs (two flights of stairs), spasticity of the ankle plantar flexor based on the Modified Asworth Scale 2, able to perform physical activity with metabolic equivalents (METs) 5, can understand and follow simple verbal instructions, and signed a written informed consent prior to participation. The exclusion criteria were : Cognitive deficit (MMSE score < 24), neurological disorders other than stroke, visual disturbances and balance disorders that make it difficult for the patient to walk steadily, heart problems, uncontrolled hypertension or severe pain, apraxia, range of motion limitation on ankle and knee joints, hemispatial neglect, taping hypersensitivity

McConnell patellar taping is a rigid taping (Strappal, BSN) which is applied by the method performed (Shin., et al, 2014) by affixing to the knee joint that has been positioned and pulled medially (from the lateral kneecap to covering the medial end of the semitendinosus muscle). and used for 30 minutes.

Walking speed is the speed at which the subject walks on a walking track. Speed is measured by dividing the distance of the walking track (10 meters) by the time it takes the subject to walk on the track. Results are expressed in meters per second $(\mathrm{m} / \mathrm{s})$

Step length is the distance from initial contact (heel to heel) of two different feet in 1 gait cycle, calculated using CMAX gait analysis software, and expressed in centimeters $(\mathrm{cm})$. Step length was assessed on the paresis (involved) side from the non paresis leg and the non paresis side from the paresis leg.

Stride length is the distance from the initial contact (heel to heel) of the same foot in 1 gait cycle calculated using CMAX gait analysis software, and expressed in centimeters $(\mathrm{cm})$. Stride length was assessed on the paresis (involved) side and non paresis leg.

The statistic in this study was performed using IBM SPSS program version 24, a statistical software. Compare before after application using taping using paired T-test. Significant if $\mathrm{p}<0,05$

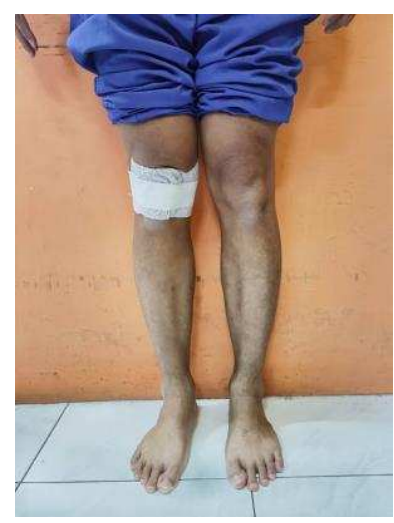

Figure 1. McConnell Patellar Taping 


\section{Results and Discussion}

Total subjects were 8 patient consisting of 4 men and 4 women. The mean onset of stroke was $3.87 \pm$ 1.13 months (onset range 2-6 months). The mean age of subjects was $46.38 \pm 11.01$ years (with an age range of 30-57 years). The average body weight of the subjects was $60.12 \pm 9.91 \mathrm{~kg}$ (with a range of $48-78 \mathrm{~kg}$ ). The average height is $158.75 \pm 6.90 \mathrm{~cm}$ (with a height range of 150-170 cm). The mean body mass index of research subjects was $23.65 \pm 2.84 \mathrm{~kg} / \mathrm{m} 2$ (with a body mass index range of 20.2-28.8 kg/m2). The number of subjects who had non hemorrhagic stroke was 6 people $(75 \%)$, while the other 2 people had a hemorrhagic stroke $(25 \%)$. All subjects in this study were first attack stroke patients $(100 \%)$. Weakness on the right side of the body were 3 people $(37.5 \%)$, left side 5 people $(62.5 \%)$.

Table 1. Subject Characteristic

\begin{tabular}{lcccc}
\hline Characteristic & N & Min & Max & Rerata \pm SD \\
\hline Total Subject & 8 & & & \\
\hline Age (year) & & 30 & 57 & $46.38 \pm 11.01$ \\
\hline Gender & $4(50 \%)$ & & & \\
\hline Men & $4(50 \%)$ & 2 & 6 & $3.87 \pm 1.13$ \\
\hline Women & & 48 & 78 & $60.12 \pm 9.91$ \\
\hline Stroke Onset (months) & & 150 & 170 & $158.75 \pm 6.90$ \\
\hline Weight $(\mathrm{kg})$ & & 20,2 & 28,8 & $23.65 \pm 2.84$ \\
\hline Height $(\mathrm{m})$ & & & \\
\hline BMI $(\mathrm{kg} / \mathrm{m} 2)$ & & & \\
\hline
\end{tabular}

Table 2. Stroke Characteristic

\begin{tabular}{lcc}
\hline & Frequency & Percentage \\
\hline Stroke type & 6 & \\
\hline Non Hemorrhagic & 2 & 75 \\
\hline Hemorrhagic & & 25 \\
\hline Paresis side & 3 & 37,5 \\
\hline Right & 5 & 62,5 \\
\hline Left & & \\
\hline Stroke attack & 8 & 100 \\
\hline $1^{\text {st }}$ attack & \\
\hline
\end{tabular}


Table 3 shows the average step length of the paresis side to non paresis side and the step length of the non paresis side to the paresis of all subjects before and 30 minutes after taping. There was an increase in the step length of the paresis side to non paresis side but it was not statistically significant $(\mathrm{p}=0.59)$ between before taping $(37.08 \pm 12.33)$ and after taping for 30 minutes $(38.03 \pm 10.77)$. For the step length of the non paresis to the paresis side, there was a decrease in step length but statistically not significant $(\mathrm{p}=0.46)$ between before taping $(39.30 \pm 13.09)$ and after taping for 30 minutes $(38.14 \pm 12.67)$.

Table 4 shows the average stride length on the paresis side and non paresis side before and after 30 minutes of taping. There was an increase in the stride length on the paresis side and non paresis side but not statistically significant, on the paresis side stride length before $(76.3 \pm 26.09)$ and 30 minutes after taping $(78.6 \pm$ 23.06), non paresis side stride length before $(74.9 \pm 23.60)$ and 30 minutes after taping $(75.3 \pm 24.20)$.

Table 3 Average step length of the paresis side to non paresis side and the step length of the non paresis side to the paresis side before and after taping

\begin{tabular}{|l|l|l|l|c|}
\hline & $\begin{array}{l}\text { Before Taping } \\
(\mathrm{cm})\end{array}$ & $\begin{array}{l}30 \text { minutes after } \\
\text { Taping }(\mathrm{cm})\end{array}$ & $\Delta$ Mean \pm SD & p value \\
\hline St L P > NP & $37,08 \pm 12,33$ & $38,03 \pm 10,77$ & $-0,95 \pm 4,77$ & 0,59 \\
\hline St L NP > P & $39,30 \pm 13,09$ & $38,14 \pm 12,67$ & $1,16 \pm 4,24$ & 0,46 \\
\hline
\end{tabular}

St L P > NP : step length of the paresis side to non paresis side, St L NP > P : step length of the non paresis side to the paresis side. Significant if $\mathrm{p}$ value $<0,05$

Table 4 Average stride length of the paresis side and non paresis side before and after taping

\begin{tabular}{|l|l|l|l|l|}
\hline & $\begin{array}{l}\text { Before Taping } \\
(\mathrm{cm})\end{array}$ & $\begin{array}{l}30 \text { minutes } \\
\text { after Taping } \\
(\mathrm{cm})\end{array}$ & $\Delta$ Mean \pm SD & value \\
\hline SL P & $76,3 \pm 26,09$ & $78,6 \pm 23,06$ & $-2,30 \pm 6$ & 0,314 \\
\hline SL NP & $74,9 \pm 23,60$ & $75,3 \pm 24,20$ & $-0,40 \pm 6,88$ & 0,874 \\
\hline
\end{tabular}

SL P: stride length of the paresis side, SL NP: stride length of the non paresis side. Significant if $p$ value $<0,05$

Table 5.5 shows the average walking speed before and 30 minutes after taping. There was an increase in walking speed and statistically significant $(p=0.026)$ between walking speed before $(0.68 \pm 0.26)$ and after taping $(0.80 \pm 0.31)$. Average increase in walking speed by $0.12 \pm 12 \mathrm{~m} / \mathrm{s}$ 
Table 4 Average walking speed before and after taping

\begin{tabular}{|l|l|l|l|l|}
\hline & $\begin{array}{l}\text { Walking speed } \\
\text { before taping }\end{array}$ & $\begin{array}{l}\text { Walking speed 30 } \\
\text { minutes after } \\
\text { taping }\end{array}$ & $\Delta$ Mean \pm SD & p value \\
\hline $\begin{array}{l}\text { Walking speed } \\
(\mathrm{m} / \mathrm{s})\end{array}$ & $0,68 \pm 0,26$ & $0,80 \pm 0,31$ & $0,12 \pm 12$ & $0,026^{*}$ \\
\hline
\end{tabular}

*significant, $\mathrm{p}$ value $<0,05$

The results of the paresis side and non paresis side stride length measurements as well as the paresis side step length increased when compared to before McConnell patellar taping was given, while the non paresis side step length decreased, but not statistically significant. Shin and colleagues in a previous study comparing McConnell patellar taping and placebo on the knee in chronic stroke patients, found a significant increase in step length and stride length in the intervention group. However, when compared with the placebo group, there was no significant difference (Shin et al., 2014). The increase in step length and stride length in this study can be explained through several mechanisms. McConnell patellar taping improves patella tracking in the patellofemoral groove by making the patella medial and this will cause patellar realignment (Shin et al., 2014). Realignment of the patella will change the leverage of the patella, maximizing the mechanical advantage of the quadriceps muscle (Herrington, 2001). Shift or realignment of the patella to the medial direction can maintain the quadriceps muscle lever arm to be longer and cause an increase in the knee extensor moment and also increase the ability of the vastus medialis muscle to produce a greater knee extensor force (Crossley et al., 2000). In Ernest et al's study, there was an increase in knee extensor moment and power in subjects who received McConnel Patellar taping when doing vertical jumps and lateral step-ups compared to placebo taping (Ernest et al., 1999). Improved knee extensor torque, moment and power associated with patellar taping was also described by Conway et al., it was said that the shift of the patella to the distal direction of the patella during knee flexion would be limited by anchoring of the patellar taping to the medial direction of the femur. This will maintain the knee extensor moment arm in a more favorable position and will improve quadriceps muscle function (Conway et al., 1992).

Ho and colleagues got different results regarding patellar realignment after using McConnel patellar taping. There was no correction of the medial alignment of the patella or changes in the contact area of the patellofemoral joint in the weight bearing condition after taping (Ho et al., 2017). In this study, the alignment of the patella was not measured, so the mechanism for increasing the step and stride length could not be determined from medial patellar realignment or not. The study of VMO (vastus medialis oblique) and VL (vastus lateralis) muscle time activity conducted by Gilleard and his colleagues on PFPS patients when going up and down stairs, found that the VMO activity time was faster than VL using patellar taping when compared to the control group. This early activity of the VMO muscle is caused by cutaneous stimulation due to taping, although the exact mechanism is not clear yet. (Gilleard et al., 1998). Christou and colleagues found an increase in VMO activity in taped PFPS patients, but this increase was not obtained through a change in the position of the patella but through increased support for the medial ligament of the patellofemoral joint and cutaneous stimulation. (Christou, 2004)

The results of measuring walking speed before and 30 minutes after McConnell patellar taping were increased compared to baseline $(0.68 \mathrm{~m} / \mathrm{s}$ to $0.80 \mathrm{~m} / \mathrm{s})$ and were statistically significant. This results are in accordance with a study conducted by Shin and colleagues in chronic stroke patients. In this study, McConnell 
patellar taping was given for 30 minutes, where the increase in walking speed was due to an increase in joint position sense and proprioception through skin, tendon and muscle stimulation. (Shin et al., 2014). Choi and colleagues who conducted a study on chronic stroke patients, also found an increase in walking speed after giving McConnel patellar taping before PNF exercise was assessed at 4 and 8 weeks compared to placebo. Although in this study the application of McConnell patellar taping increased walking speed, but when compared to the kinesiotaping group the results were still lower. (Choi et al., 2016).

Walking speed is the result of cadence multiplied by step or stride length (Silva and Jacinto, 2020). In this study, the increased walking speed could be caused by an increase in stride length and step length although not statically significant. Cadence also can increase walking speed but in this study, cadence was not measured The average increase in walking speed in this study was $0.12 \pm 12 \mathrm{~m} / \mathrm{s}$, from $0.68 \mathrm{~m} / \mathrm{s}$ before taping to $0.80 \mathrm{~m} / \mathrm{s}$ after McConnell patellar taping. A walking speed of $0.80 \mathrm{~m} / \mathrm{s}$ is the recommended walking speed for the purposes of effective ambulation in the community, for example crossing a road (Beyaert et al., 2015). Increase walking speed was also found in a study conducted by Shin and Chung in chronic stroke patients who were given McConnell patellar taping while exercising on a treadmill for 30 minutes for 4 weeks when compared to the control group (without using taping). McConnell patellar taping in addition to stimulating the skin and tendons that improve joint position sense, proprioception and alignment of the patella can also cause pressure on the knee joint which causes joint stability. This is what causes an increase in walking ability, including walking speed (Shin and Chung, 2015)

\section{Conclusion}

Application of McConnell patellar taping on the paresis side of the knee in sub acute stroke patient for 30 minutes, increased walking speed. This application thought be useful for sub acute stroke patient for improvement on walking speed. Further research is needed to evaluate long term effect of McConnell patellar taping in stroke patient

\section{References}

Abbas G and Diss C. 2011. Patellar tracking during the gait cycle. Journal of Orthopaedic Surgery, pp 288-291. Abulhasan J and Grey M. 2017. Anatomy and physiology of knee stability. Journal of functional morphology and kinesiology.

Afonso M. 2015. Modelling the Gait of Healthy and Post-Stroke Individual.

Beyaert, C., Vasa, R and Frykberg, G. 2015. Gait post stroke : Pathophysiology and rehabilitation strategies. Clinical Neurophysiology, pp335-355.

Chae, S.H., Kim, Y.L., and Lee, S.M. 2017. Effect of phase proprioceptive training pn balance in patient with chronic stroke. The Journal of Physical Therapy Science, pp 839-44

Chia, F., Kuys, S., and Choy, N.L. 2019. Sensory retraining of the leg after stroke: systematic review and metaanalysis. Clinical Rehabiliatation, vol 33, pp 964-979

Choi, Y.K., Park, Y.H. and Lee, J.H., 2016. Effects of Kinesio taping and Mcconnell taping on balance and walking speed of hemiplegia patients. Journal of physical therapy science, 28(4), pp.1166-1169.

Christou EA. 2004. Patellar taping increases vastus medialis oblique activity in the presence of patellofemoral pain. J Electromyogr Kinesiol, p 495-504.

Conway, A., Malone, T.R. and Conway, P., 1992. Patellar alignment/tracking alteration: effect on force output and perceived pain. Isokinetics and Exercise Science, 2(1), pp.9-17.

Coupland, A.P., Thapar, A., Qureshi, M.I., Jenkins H., and Davies, A.H., 2017. The Definition of Stroke. Journal of The Royal Society of Medicine, Volume 110, pp 9-12.

Crossley, K., Cowan, S., Bennel, K.L., and McConnell, J., 2000. Patellar taping : is clinical success supported 
by scientific evidence?. Harcourt publishers Ltd.

Ernst, G.P., Kawaguchi, J., Saliba, E., 1999. Effect of patellar taping on knee kinetics of patients with patellofemoral pain syndrome. J Orthop Sports Phys Ther.;29: p 661-667

Flandry, F., and Hommel, G., 2011. Normal anatomy and biomechanics of the knee. Sports Med Arthrosc Rev , vol 19, pp 82-92.

Gillen, G. 2016. Stroke Rehabilitation : A Function-Based Approach, Fourth Edition. Elvesier inc

Gilleard, W., McConnell, J., Parsons, D., 1998. The effect of patellar taping on the onset of vastus medialis obliquus and vastus lateralis muscle activity in

persons with patellofemoral pain. Phys Ther.;78: pp 25-32.

Gulati, A., Mcelrath, C., Wadhwa, V., Shah, J., Shah, J.P., and Chhabra A, 2018 . Current clinical, radiological and treatment perspectives of patellofemoral pain syndrome. British Institute of Radiology.

Harvey, R.L. 2011. Stroke syndrome. In Braddom, RL: Physical medicine \& Rehabilitation. 4th ed, Philadelphia: Elsevier Saunders.

Herrington, L. 2001. The effect of patellar taping on quadriceps peak torque and perceived pain: a preliminary study. Phys Ther Sport, p 23-28.

Ho, K.Y., Epstein, R., Garcia, R., Riley, N., Lee, S.P. and Turner, C., 2017. Effects of patellofemoral taping on patellofemoral joint alignment and contact area during weight bearing. journal of orthopaedic \& sports physical therapy, 47(2), pp.115-123.

Jacinto, J., 2020. Velocity Determinants in Spastic Patients after Stroke-A Gait Analysis Study. Neurology International, 12(3), pp.48-54

Jimenez, M.C. 2017. Normal Changes in Gait and Mobility Problems in the Elderly. Phys Med Rehabil Clin N Am 28, pp 713-725.

Kharb, A., Saini, V., Jain, Y.K., and Dhiman, S. 2011. A Review of Gait Cycle and Its Parameters. International Journal of Computational Engineering \& Management, p: 78-83

Kim, H.Y., Kim, K.J., Yang, D.S., Jeung, S.W., Choi, H.G., and Choy WS, 2015. Screw-home movement of tibiofemoral joint during normal gait: three-dimensional analysis. Clinic in orthopedic surgery, vol 7, pp 303309.

Lan, T., Lin, W., Jiang, C., and Chiang H, 2010. Immediate effect and predictors of effectiveness of taping for patellofemoral pain syndrome. The American Journal of Sport Medicine, Vol. 38, pp 1626-1630.

Leibbrandt D and Louw Q. 2015. The use McConnell taping to correct abnormal biomechanics and muscle activation pattern in subject with anterior knee pain : a systematic review. The Society of physical therapy science.

Li, S., Franscisco, G., and Zhou P, 2018. Post-Stroke Hemiplegic Gait : New Perspectiveand Insights. Frontiers in physiology, Volume 9.

Loudon, K., 2016. Biomechanics and pathomechanics of the patellofemoral joint. The International Journal of Sports Physical Therapy, vol 11, p: 820-828

McGee, S. 2018. Evidence-based physical diagnosis. Elvesier inc , 4th edition, p: 45-58.

Neumann, D. 2010. Kinesiology of the musculoskeletal system. Mosby Elvesier, 2nd edition, pp: 520-554.

Ovbiagele B and Nguyen-Huynh M, 2011. Stroke Epidemiology : advancing our understanding of disesase mechanism and therapy. The journal of the American society for experimental NeuroTherapeutics.

Pfeiffer, P., DeBeliso, M., Shea, K., Kelley, L., Irmischer, B., and Harris C, 2004. Kinematic MRI assessment of McConnell taping before and after exercise. The American Journal of Sport Medicine, vol. 32, p : 621-628. Ratnawati, A. 2014. Panduan Rehabilitasi Stroke. PERDOSRI, pp. 8-32.

Riskesdas, 2018. Riset Kesehatan Dasar. Jakarta: Badan Penelitian dan Pengembangan Kesehatan Kementerian Kesehatan RI.

Shelburne, K.B., Torry, M.R., and Pandy MG, 2005. Muscle, ligament, and joint-contact forces at the knee during walking, in Medicine and science in sports and exercise, American college of sport medicine, pp 19481956 
Shin, J. and Chung, Y.J., 2015. The effect of treadmill gait training with patellar taping on gait abilities in chronic stroke patients. Physical Therapy Rehabilitation Science, 4(2), pp.94-102.

Shin, J., Mun, M., and Chung Y, 2014. The immediate effect of patellar taping on balance and gait ability in individuals with chronic stroke. Pysical Therapy Rehabilitation Science.

Kessner, S., Schlemm, E., Cheng, B., Bingel, U., Fiehler, J., Gerloff, C and Thomalla G, 2019. Somatosensory deficits after ischemic stroke : time course and association with infarct location. American Heart Association, p1116-1123

Song, C., Lin, J., Jan, M., and Lin Y, 2011. The role of patellar alignment and tracking in vivo : the potential mechanism of patellofemoral pain syndrome. Physical therapy in sport, p: 140-147.

Stein, J and Brandstater M. 2010. Stroke Rehabilitation. Delisa 's Physical Medicine \& Rehabilitation, p: 551553

Stewart, T.D and Hall, R. 2006. Basic biomechanics of human joints: hips, knees and the spine, Current Orthopaedics, vol. 20, pp 23-31.

Whittle, M.W. 2007. Gait Analysis: an introduction. 4th ed., Butterworth Heinemann, pp. 223-4.

Woolley, S. 2001. Characteristics of Gait in Hemiplegia. Topic Stroke Rehabilitation, p: 1-18

Zorowits, R.D., 2010. Stroke. In: Cuccurullo SJ: Physical Medicine and Rehabilitation Board Review. 2nd ed.

New York: Demos medical, pp. 40-87. 